\title{
KERAGAMAN SPESIES LALAT BERDASARKAN LOKASI PENANGKAPAN DI PASAR INDUK JAKABARING PALEMBANG
}

\author{
Yunita Panca Putri ${ }^{1 *}$ \\ ${ }^{\text {I}}$ Program Studi Biologi, Fakultas Matematika dan Ilmu Pengetahuan Alam \\ Universitas PGRI Palembang \\ *e-mail: yunita_pp12@yahoo.co.id
}

\begin{abstract}
The variation of bait used can make the fly interested. Flies eat food eaten by humans everyday, such as sugar, milk, protein, fat and other foods, human waste and blood. Flies also like foods that are undergoing a process of fermentation / decay. Flies that perch on food disrupt performance and potentially carry contaminants and reduce the health quality of food ingredients. Flies can be vectors of diseases that are endemic and need serious handling if an area is found with high density flies, therefore it is known the diversity of species of flies based on the fishing location at the Jakabaring market in Palembang. This study aims to identify the diversity of species of flies found in the Jakabaring Central Market Palembang. The place for sampling flies is the main market of Jakabaring Palembang, while the place of research is conducted at the Laboratory of Biology, Science Center, University of PGRI Palembang. The results obtained were 5 species of flies found in the main market of Palembang's Jababaring namely Muscadomestica, Chrysomyasp., Lucilia sp., Sarcophaga sp., And Fannia sp. and the fish plot is the catching location with the most number of flies found.
\end{abstract}

Keywords: House fly; market of Jakabaring Palembang; Feed / food variations

\begin{abstract}
ABSTRAK
Variasi umpan yang digunakan dapat membuat lalat tertarik. Lalat memakan makanan yang dimakan manusia setiap hari, seperti gula, susu, protein, lemak dan makanan lain, kotoran manusia dan darah. Lalat juga menyukai makanan yang mengalami proses fermentasi / pembusukan. Lalat yang hinggap pada makanan mengganggu kinerja dan berpotensi membawa kontaminan dan mengurangi kualitas kesehatan bahan makanan. Lalat dapat menjadi vektor penyakit yang endemik dan perlu penanganan serius jika suatu daerah ditemukan dengan lalat kepadatan tinggi, oleh karena itu perlu diketahui keanekaragaman spesies lalat berdasarkan lokasi penangkapan di Pasar Induk Jakabaring Palembang. Penelitian ini bertujuan untuk mengidentifikasi keanekaragaman spesies lalat yang ditemukan di Pasar Induk Jakabaring Palembang. empat pengambilan sampel lalat adalah Pasar Induk Jakabaring Palembang, sedangkan tempat penelitian dilakukan di Laboratorium Biologi, Science Center, Universitas PGRI Palembang. Hasil penelitian diperoleh 5 jenis lalat yang ditemukan di Pasar Induk Jababaring Palembang yaitu Musca domestica, Chrysomya sp., Lucilia sp., Sarcophaga sp., dan Fannia sp. dan lokasi ikan adalah lokasi penangkapan dengan jumlah lalat terbanyak.
\end{abstract}

Kata kunci: Lalat, Pasar Induk Jakabaring Palembang, Variasi pakan / makanan. 


\section{PENDAHULUAN}

Lalat memiliki kemampuan reproduksi yang cepat. Siklus hidup lalat memerlukanwaktu sekitar lima belas hari. Lalat tidakdapat diberantas habis tetapi dapat dikendalikan sampai dengan batas yang tidak membahayakan atau menimbulkan masalah bagi kesehatan masyarakat, pengendalian lalat dapatdilakukan dengan berbagai cara baik secarakimia, fisik dan biologis.Bahan pangan yang dihinggapi lalat dapat berpotensi sebagai sumber penyakit bagi manusia

Variasi umpan yang dipergunakan dapat membuat lalat tertarik. Lalat memakan makanan yang dimakanoleh manusia sehari-hari, seperti gula, susu,protein, lemak dan makanan lainnya, kotoran manusia serta darah. Lalat juga menyukaimakanan yang sedang mengalami proses fermentasi/pembusukan. Bentuk air berwarna kehitaman dan berbau. Kondisi lingkungan tersebut dapat

mendukung lalat untuk mendapatkan makanan dan berkembangbiak.

Lalat yang hinggap pada bahan makanan mengganggu performance dan berpotensi membawa kontaminan serta mengurangi mutu kesehatan bahan makanan. Lalat dapat sebagai vektor penyakit yang bersifat mewabah dan perlu penanganan serius apabila suatu daerah ditemukan lalat dengan kepadatan yang tinggi. Oleh karena itu perlu dilakukan penelitian jenis-jenis lalat berdasarkan lokasi pengangkapan di Pasar Induk Jakabaring Palembang.Hasil penelitian Putri dkk., (2013), mengenai keanekaragaman lalat (Cyclorrapha: Diptera) pada lokasi penjualan ikan segar di Kota Padang ditemukan 5 species lalat yaitu Musca domestica, Chrysomya megacephala, Lucillia sp., Calliphora sp., Sarcophaga sp dan species yang paling dominan adalah Musca domestica. makanannya cairatau makanan yang basah, sedang makananyang kering dibasahi oleh ludahnya terlebihdahulu, baru dihisap (Nadeak $d k k$., 2015).

Pasar Jakabaring merupakan pasar induk di kota Palembang, karena menyuplai sayur, buah maupun ikan/daging dalam jumlah banyak dari berbagai daerah di kota Palembang, sehingga para pedagang dapat membeli dalam jumlah banyak kebutuhan dengan harga yang lebih murah, untuk kemudian dijual kembali. Pasar merupakan tempat manusia melakukan aktivitas jual beli untuk mendapatkan berbagai jenis bahan makanan, seperti ikan, daging, sayur dan buah sehingga dari aktivitas tersebut akan menghasilkan sampah dan menjadikan lingkungan pasar menjadi kotor dan bau. Belum lagi tumpukan-tumpukan sampah dalam volume yang lebih kecil di beberapa sudut lorong pasar. Saluran air dari limbah pasar kerap tersumbat dengan Penelitian ini bertujuan untukmengidentifikasi keragaman jenis lalat yang terdapat di Pasar Induk Jakabaring Palembang. Dari hasil penelitian ini diharapkan dapat berkontribusi memberikan informasi tentang jenis-jenis lalat yang terdapat di Pasar Induk Jakabaring Palembang, sehingga diperoleh data untuk pengendalian lalat.

\section{METODE PENELITIAN}

\section{Waktu dan Tempat}

Penelitian dilakukan pada bulanJanuari sampai bulan Mei 2015. Tempat pengambilan sampel lalat adalah Pasar Induk Jakabaring Kota Palembang. Sedangkan tempat penelitian dilakukan di Laboratorium Biologi Science Center Universitas PGRI Palembang. 


\section{Alat dan Bahan}

Alat-alat yang digunakan pada penelitian ini meliputi jaring penangkap lalat (insect net), kertas umpan berperekat, botol koleksi, mikroskop, optilab, pinset, kamera,

\section{CARA KERJA}

\section{Penangkapan lalat}

Penangkapan lalat dengan menggunakan insect net, dan menggunakan kertas umpan berperekat yang diletakkan pada setiap titik pengambilan sampel di masing-masing lokasi penelitian dari pukul 08.00 WIB sampai pukul 10.00 WIB. Penangkapan lalat diambil sebanyak 3x penangkapan. Dilakukan 1 minggu sekali,selama 3 minggu Penentuan lokasi pengambilan sampel lalat ialah plot jualan sayuran, plot jualan buah-buahan, plot jualan ikan, plot jualan daging, plot jualan ikan asin.

\section{IdentifikasiLalat}

Lalat diidentifikasi berdasarkan morfologinya, seperti ukuran tubuh,warna tubuh, karakteristik kepala, alat mulut, antenna, tungkai/kaki, dan sayap menggunakan buku Borror et al., (1992) dan Kalshoven (1981). Identifikasi lalat dikerjakan secara makroskopis dan mikroskopis (dengan Stereomikroskop) dan didasarkan pada semua gambaran dalam struktur anatomis luar tubuh lalat.

\section{HASIL DAN PEMBAHASAN}

Hasil penelitian tentang Keragaman spesies lalat berdasarkan lokasi penangkapan di Pasar Induk Jakabaring Palembang ditampilkan padaTabel 4.1

Tabel 4.1 Spesies lalat yang ditemukan di Pasar Induk Jakabaring Palembang

\begin{tabular}{|c|c|c|c|c|c|c|c|}
\hline \multirow[t]{2}{*}{ Famili } & \multirow[t]{2}{*}{ Spesies } & \multicolumn{5}{|c|}{$\begin{array}{c}\text { Lokasi penangkapan di Pasar Induk } \\
\text { Jakabaring Palembang } \\
\end{array}$} & \multirow[t]{2}{*}{ Total } \\
\hline & & $\begin{array}{l}\text { Plot } \\
\text { sayur }\end{array}$ & $\begin{array}{l}\text { Plot } \\
\text { ikan }\end{array}$ & $\begin{array}{l}\text { Plot } \\
\text { daging }\end{array}$ & $\begin{array}{l}\text { Plot } \\
\text { buah }\end{array}$ & $\begin{array}{l}\text { Plot ikan } \\
\text { asin }\end{array}$ & \\
\hline \multirow[t]{2}{*}{ Calliphoridae } & Chrysomyamegacephala & - & 28 & 19 & - & 8 & 56 \\
\hline & Lucilia sp. & - & 16 & 5 & - & - & 21 \\
\hline \multirow[t]{2}{*}{ Muscidae } & Fannia sp. & 7 & & 6 & 5 & 6 & 26 \\
\hline & Musca domestica & 32 & $\begin{array}{c}2 \\
30\end{array}$ & 18 & 14 & 33 & 127 \\
\hline Sarcophagidae & Sarcophagasp. & - & - & - & - & 2 & 2 \\
\hline Jumlah & & 39 & 76 & 48 & 19 & 49 & 232 \\
\hline
\end{tabular}


Pada Tabel 4.1 spesies lalat yang ditemukan pada lokasi Pasar Induk Jakabaring Palembang ada 5 spesies yaitu Chrysomya megacephala, Musca domestica, Lucilia sp., Sarcophaga sp. dan Fannia sp.

Dari ke-5 plot di lokasi Pasar, spesies lalat yang selalu ditemukan yaitu M. domestica dan Fannia sp. dari Famili Muscidae. Menurut Lilies (1991), Famili Muscidae dapat ditemukan di semua tempat atau bersifat kosmopolitan. Hal ini disebabkan $M$. domestica termasuk hewan omnivorous (pemakan segala). Lalat ini juga mempunyai daya reproduksi yang cukup tinggi dan dapat menghasilkan beberapa generasi dalam 1 tahun (Astuti dan Pradani, 2010).

$$
\text { C.megacephala banyak }
$$

ditemukan di plot penjualan daging disebabkan karena, plot penjualan daging menyediakan tempat dan makanan bagi kelangsungan hidup lalat tersebut. Lalat akan mengunjungi suatu tempat jika ada sumber makanan dan tempat meletakkan telurnya. Hal ini sesuai dengan yang ditemukan oleh Yuriatni (2011), pada penelitiannya di kota Solok Sumatera Barat, bahwa lalat C. Megacephala dominan ditemukan di tempat pengolahan ikan Pasar Raya.

Lucilia sp. hanya ditemukan di plot jualan ikan segar dan daging, dengan jumlah terbanyak terdapat di plot jualan ikan segar. Ini dikarenakan plot ikan segar dan daging mendukung untuk hidup dan berkembangbiak lalat, disekitar lokasi penjualan ikan segar juga terdapat genangan air, tumpukan limbah ikan, kondisi demikian dapat menyebabkan lokasi penjualan ikan segar menjadi kotor dan lembab, yang akhirnya juga mendukung perkembangan hidup lalat.

Sarcophaga sp. hanya ditemukan 2 ekor di plot jualan ikan asin. Sarcophaga sp.tertarik pada daging atau bangkai, dan juga dikenal menyebabkan myiasis pada makhluk hidup. Menurut Wahyu (2009), Sarcophaga sp. tertarik pada mayat hampir di semua situasi, terpapar ataupun terlindung dari matahari, lingkungan basah ataupun kering, di dalam ataupun luar ruangan.

\section{KESIMPULAN}

Dari hasil penelitian terhadap Keragaman Spesies Lalat berdasarkan jenis makanan di Pasar Induk Jakabaring Palembang, maka dapat disimpulkan:

1. Spesies lalat di Pasar Induk Jakabaring Palembang ditemukan 5 spesies, yaitu $M$. domestica, $C$. megacephala, Lucilia sp., Sarcophaga sp., dan Fannia sp.

2. Plot ikan adalah lokasi penangkapan yang paling banyak jumlah lalat ditemukan.

3. Spesies lalat yang ditemukan pada setiap plot jenis makanan adalah Musca domestica.

\section{DAFTAR PUSTAKA}

Borror, D.J., C.A. Triplehom., and N.F. Jonhson, 1992. An Introduction To The Insect TerjemahanPartosoedjono, $S$ danMukayat, D.B. Gajah MadaUniversitas Press. Yogyakarta: xviii+1009 hlm.

Erpina Santi Meliana Nadeak MSR, Rwanda T, iskandar I. 2015. Efektifitas Variasi Umpan Dalam Penggunaan Fly Trap Di Tempat Pembuangan Akhir Ganet Kota Tanjungpinang. Jurnal Kesehatan Masyarakat Andalas. 10(1): 82-86.

Kalshoven LGE. 1981. Pest of Crops in Indonesia. Revised and Translated by van der Laan. PT. Ichtiar Baruvan Hoeven. Jakarta.

Lilies C. 1991. Kunci Determinasi Serangga. Kanisius. Jakarta: xii+223 hlm. 
Putri PY, Jasmi, Armein, dan Zeswita L. 2013. Keanekaragaman Lalat (Cyclorrapha: Diptera) Pada Lokasi Penjualan Ikan Segar Di Kota Padang. Universitas Andalas Padang. Jurnal of Biological Education. 2(2) : 1-6.

Wahyu N, Suharto G, dan Kirana S. 2009. Perbedaan Genus Larva Lalat Pada Bangkai Tikus Wistar Diletakan Di Darat, Air Tawar dan
Air Laut. Laporan Akhir Penelitian Karya Tulis Ilmiah. Fakultas Kedokteran Universitas Diponegoro. Semarang: $29 \mathrm{hlm}$.

Yuriatni. 2011. KeanekaragamanLalat (Cyclorrapha: Diptera) Dan ParasitUsus Yang Dibawanya Di Kabupaten Dan Kota Solok Sumatera Barat .Tesis. Padang: Pasca Sarjana Universitas Andalas Padang. 